\title{
How to Integrate Student Internships into Legal Studies Research and Curriculum: A Case Study
}

\author{
Jill O. Jasperson \\ Woodbury School of Business, Utah Valley University, USA
}

Copyright $\subset 2017$ by authors, all rights reserved. Authors agree that this article remains permanently open access under the terms of the Creative Commons Attribution License 4.0 International License

\begin{abstract}
The aim of this article is to answer the 'how' and 'why' of a Legal Studies internship experience at a public university. Internship is an integral part of student learning. Although the Faculty/Organizers conducted a free legal clinic for five years previous, this case study discusses a first time internship attempt by faculty and administration to meet the needs of students. This descriptive case study discusses students' research during the internship as well as various assignments and reflective papers. Problems with current practices are identified as well as best practices encountered.
\end{abstract}

Keywords Internship, Legal Studies, Law, Clinic, How and Why, Work, Legal, Pro Bono, Attorney, Lawyer, Paralegal, Case Study, Curriculum, Student Learning, Descriptive, Research, Assignments, Reflection Papers, Reflective, Paralegal Studies, Law Students, Legal Students, Legal Studies Students, Free Legal Clinic, Work Experience, Education, Semester, Project, Event, UVU, Utah, Utah Valley University

\section{Introduction}

\subsection{Internship Definitions}

Higher education institutions around the globe define their vision of internship. Ciafolo [1] states that the legitimacy of internships for academic credit can be controversial.

Kuh [2] cites the importance of high impact internships. In particular for legal students, the influential MacCrate Report [3] reported that internships are not as meaningful as learning from faculty in the classroom and clinics.

Other literature states that academic and community engagement is successful through successful internships. Internships enhance employability. See Coco [4] and Gault, Leach \& Duey [5].

There can be a confusing epistemological cacophony of voices vying for both student and faculty knowledge.
Internship is perceived in a variety of ways. However, how an internship is conducted is important in student learning, as well as why the student is doing what they are doing.

Utah Valley University's [6] definition is “an internship is a pre-professional career training experience with intentional learning goals. Internships provide real world experience to help students explore or gain the relevant knowledge and skills required to enter a particular career field."

\subsection{Methodology}

The methodology [7] changed the student's ideals and paradigms of legal studies education. This case study revolves around the hypotheses that a one-night legal clinic could stand alone as an internship opportunity for legal studies students.

A how and why case study came into practice. [8] A semester long experience for a one-night clinic was the goal. There were no designs to work in a law office or corporate legal center. An IRB was obtained for client, student and attorney surveys during the event for additional data resources.

Organizer faculty and staff employed a heuristic teaching model so that students could learn on their own what worked well for them during the internship process. There were meaningful assignments created that this article will discuss. In retrospect, the author believes this experience was a precursor internship for legal studies students who wanted to get their 'feet wet' with the legal community and service. The internship attracted a few students who were willing to do a semester long project for a one-night event.

\subsection{Background}

The internship would not have occurred without the groundwork laid in the previous five years. The American Bar Association kicked off its first annual "Celebrate Pro Bono" week in October 2009. This included celebrations throughout the country, specifically promoting gatherings to foster pro bono legal services.

Utah Valley University, Woodbury School of Business, 
and the Legal Studies Department joined in with a Free Legal Clinic in October of that year. The event was a huge effort, consisting of twenty-plus attorneys and fifty-plus students participating and ready to render services. To the shock of the organizers, the public came out in huge numbers-over one hundred and fifty people, despite the cold weather.

The effort expanded and became a staple for Legal Studies students, UVU staff and faculty, and the surrounding community in the following years: 2010, 2011, 2012, 2013 and 2014. Touted as the Largest One-Night Free Legal Clinic in the country, attorney numbers rose at its peak to thirty attorneys. These attorneys worked for three hours for just one evening solving problems for dozens seeking help, with no remuneration, accounting for legal service costs of $\$ 25,000$ or more. The event expanded, and the footprint of pro bono in the community became larger through the UVU Free Legal Night recognition.

In 2013, Organizers applied to the university for seed money to help with the burgeoning interest in the one-night clinic and received grant money to pay an administrative assistant and for additional marketing materials.

Organizers also realized the importance of sustainability, obtained IRB approval and surveyed students, attorneys, and clients with a five-minute survey to gauge continued success. The organizers faculty were elated with the survey results, and looked forward to 2014.

Two thousand fourteen was a banner year for the Free Legal Clinic. It was the sixth year for the clinic. It was coming into its own, but further help was needed as numbers grew.

Organizers were able to use the same assistant with leftover monies to move the work forward. In past years, Faculty gave engaged learning points to students for helping with the Free Legal Clinic. Organizers decided it was time that students should receive credit for participating and the Free Legal Clinic internship evolved.

\subsection{Procedures}

Faculty obtained an email list of all students enrolled in the legal studies program Freshman-Senior years. All students were contacted the summer before Fall Semester 2014 started. Faculty and staff had a large organizational meeting the second week of class. Students were recruited, and procedures explained how to sign up through the administration for the internship, how the UVU Free Legal Clinic was conducted, and why the event was being held. Student questions were addressed and eleven students became involved. Staff made immediate assignments as discussed below.

\subsection{Student Internship Curriculum: Activities \& Assignments}

Past years had taught the Organizers that how to market the event was key to bringing in more clients. Half of the pre-event organization centered on contacting people. The eleven internship students fell into five outreach areas:

Community Outreach One

Community Outreach Two,

Community Outreach Three,

UVU and Classroom Outreach, and

Attorney Outreach and Event Details

Community Outreach One, Two and Three consisted of marketing duties. This was not something Legal Studies students studied or had experience dealing with. Heuristically, the process of developing how to market was a good experience for the students, even though it was out of their comfort zone.

Interns contacted courts, county and local government agencies, community centers, and schools. They contacted these entities and inquired about poster and flyer requirements. Inquiries led to return calls and poster placements. How did the outreach students do? Here are some of their thoughts:

"I was so nervous to reach out to people to inform them about the legal clinic. In order to conquer my fear of speaking to people I do not know, I wrote a script for myself. The lesson that was learned from the part in the pre-clinic preparation was how to help my fear of calling others. This fear was aided by writing a 'manuscript' to help me through the phone call with the necessary information."

"I completed 30 hours of service [for pre-event], this included putting up flyers, posters, ads on the Internet and on campus and as well as the community. And translating flyers, posters, and papers."

"I tried the ACLU which I thought would be another good option to advertise with."

"I learned through talking with the people that would be in charge of placing the flyers out at all of these community outreach groups, that they were very excited to have at least flyers, and most took a poster also. They took quite a few flyers because they thought the clients they help through their resources would also benefit."

Other Outreach methods incorporated social media sites, blogs, city and town websites, along with mayoral websites to contact administrators for posting event information. Students unfolded further outreach and researched further ideas for contact: they figured how to translate surveys and intake in Spanish. They also visited other outreach areas, which were not on the list. Here are some of the comments:

"I had to translate a few documents from English to Spanish that challenged me and I had to really focus because I did [not] want to mess up, so I had to do the best of my work."

"I also visited local senior homes and got positive feedback from that. At one home I called, they asked me if UVU would [be] interested in holding a seminar at their home for legal advice."

UVU and Classroom Outreach consisted of interns contacting the school of business classes. Interns encouraged professors, students and their families to come to the event. 
This Outreach group also perfected the Pro Bono surveys previously used in antecedent years. Interns edited line by line, and reworked the format. Comments include:

"One of my tasks that I was assigned were class visits. In the beginning, the class visits sounded intimidating, but I stuck to it. I loved going to different classes with people who were also in the internship because it was reassuring. After the first time, I felt confident and it wasn't very difficult. I think that having students visit classes was one of the most efficient ways of getting the word out."

Attorney Outreach and Event Details consisted of interns making reminder calls to attorney offices, making information calls and emails to update attorney practice areas, finding Spanish speakers, taking photos of the event, along with doing client intake and registration during the event. Interns helped create and send out the Attorney Outreach letter.

Examples of the attorney outreach:

"Dear

Thank you for volunteering your time for our legal consultation clinic at UVU. It is only three weeks away!

This signifies special support from you as we make strides to fill the justice gap in County.

We are excited that you will join us for this Sixth Annual event:

Sixth Annual Clinic

Date

Place and Time for Attorney Dinner

Clients-(First Come, First Serve) meet in for

intake. Consultations $7-9 \mathrm{pm}$ in assigned consult/study rooms:

You are assigned legal interns, assistants and/or law students to observe you and timekeepers to keep track of the 15-20 minute consultations. If you need anything done throughout the evening, your assistants and timekeeper are there to help. We also have runners to help clients find your consult room. Once you find your consultation room, please remain there until the evening is over.

We will have intake forms available for the clients, which they will fill out before they meet with you. After the night is over, make sure that your assistants (or you) return all the intake sheets with your notes to me or to the intake desk.

Access to justice is the cornerstone of our democracy. Many individuals are unaware of what constitutes a legal problem. Your help is especially important during this interesting economic time.

Should you have further questions that I have failed to cover, please email or call at

Thank you again for your participation."

Many of these activities seem mundane and not related to legal work. However, literature has shown that academic benefits may be due to aspects of the non-academic environment in which the internship happens. See Binder [8].

\subsection{Student Research: Assignments and Activities}

Additional assignments covered the why of the internship. Each intern had to interview an attorney, a legal assistant, and go to court and report.

Interview questions included 'why' questions that helped interns search deeper as to why they would want to participate in the legal profession.

Some of these questions were:

Why did attorney decide to attend law school?

Why did attorney choose/want to go to a particular law school?

Why did attorney choose the legal profession?

Why did attorney choose to do pro bono work this year?

Why do you do law?

Why did legal assistant choose the legal profession?

Why did legal assistant choose to do the specialized job they do?

Why legal assistants cannot offer legal advice?

Why do you do law?

Why did the judge rule the way she/he did?

Why is the judge so strict or confusing?

Why are there court standards of dress?

Why are there certain court protocols?

Why is there a reading of rights in court?

Why is there a jurisdiction issue?

These 'why' questions also spurred other 'why' questions. Interns would have to research law school, curriculum, legal assistant curriculum, pro bono, court procedures, judgeships, jurisdiction, constitutional issues, et cetera on their own. Through the gnawing questions of how and why of the whole internship, interns had to research in all phases.

\subsection{Additional Research}

There were additional documents that students had to create, including the legal clinic release form, and intake documents. A sample of these is also included:

Release form:

"With respect to any conversation I may have with any attorney as part of this legal clinic, I understand, agree, and acknowledge by signing this agreement that:

Most factual and legal issues are complex, and it is possible that the attorney and I will each misunderstand what the other is trying to communicate;

Although the attorney may take notes during our conversation, the attorney will not keep such notes or other written record of our conversation;

I have no obligation to the attorney, and the attorney has no continuing obligation to me unless I choose to retain the attorney for further services beyond the legal clinic consultation;

Any information that I may receive is general information that may not apply to my specific situation or legal problem 
and, therefore, cannot be relied upon;

It is not the intent of the attorney to provide me with specific legal advice; it is not possible under these limited circumstances for the attorney to identify and explore all relevant issues in order to provide me with specific legal advice;

The attorney does not represent me or my interests in any legal matter;

If I later request the attorney to provide me with legal representation or assistance, it will be necessary for me to discuss such representation with the attorney and for us to enter into a written fee/representation agreement;

Any actions I choose to take or not take or decisions I make or do not make in the future will not be made in reliance on any information I obtain from an attorney at the legal clinic.

I have read, understood, and agree to the terms written above.

Date, Printed Name and Signature were on the bottom of the document."

\section{Client intake form:}

The client intake form contained the typical name, phone number for work, home and cell phone. Address with city, state and zip code inserted, along with email and best time to contact (morning, afternoon, evening) was included.

Questions about case information: opposing party, opposing attorney, related parties and prior attorney names were asked. This was to give the clinic attorney context for the case and to check conflicts of interest.

Further questions in the intake form asked for area of law in order to assign the case to the correct practicing attorney.

Legal services mainly delivered during the clinic were in the areas of family law, employment law, criminal law, consumer/bankruptcy law, landlord/tenant law, immigration law, and estate planning.

The intake form also asked the client for a brief description of their legal concern.

This intake form was very helpful to all the participants. It gave the attorney a brief idea how long the concern persisted. Intake workers could send a client to a senior attorney with further experience if necessary.

\section{Results}

Legal Studies students study paralegal curriculum. Therefore, they cannot offer legal advice in most states. However, after all their hard work, the interns were able to observe attorneys and clients in action in an intimate setting.

The lawyers and clients, along with their intern paralegals listened to client stories in small study rooms throughout the university library. They listened to attorney advice given to clients; they were able to interact with attorneys one-on-one. They had direct contact with attorneys in an attorney-client relationship for several hours, something that most aspiring paralegals cannot do. This built confidence and empowerment; it showed the real expectations of the legal field.

Networking is key to the employability link. Interns had many opportunities for networking the night of the event, and through pre-event marketing and outreach activities.

Community members received legal advice, and interns can attribute marketing strategies to those attending. Community engagement and outreach brought sixty-five clients to the 2014 event.

After careful consideration, Organizers and Faculty considered the results of how well the idea of an internship worked. These results had mixed reviews of differences/disadvantages as well as advantages.

Differences/disadvantages:

- The UVU Free Legal Clinic internship did not fit perfectly into the definition of the university's academic policy

- The internship spanned a short duration

- The internship did not take place in a law office or legal workplace

- The internship was in preparation and participation for one event

- Many of the internship pre-event activities centered on event planning, marketing and prosaic activities

- A few students were involved - thus creating a very small sample from the 127 enrolled Legal Studies students

- $\quad$ No specific quantitative data taken during the internship except satisfaction surveys from clients, attorneys and student workers - emphasis was on the logistics of the event.

- Learning goals were sporadic and sometimes unintentional because of organizer's first year learning curve. Students did not enjoy the Socratic approach and ostensible lack of direction.

There were many advantages to this 2014 internship.

The advantages included:

- Short amount of concentrated time building relationships

- Qualitative data was taken from interns based from reflection papers

- Observation and research of legal work with client and attorney during the event

- Unequivocal contact with thirty attorneys during event

- Direct contact with several judges during the event

- Association with community channels to those seeking legal help before and during event

- Direct contact with the courts by placement of posters and marketing

- Enhanced resume or grad school application

- Legal theory perspicacity

- Engaged learning opportunity

- Legal community attention and assiduity

- Foundational fulcrum to launch into the legal community

- Students felt more confident in their abilities 
- Students can decide if law is the appropriate career for them

Not only were interns and students able to observe and interact, they immersed themselves in professional and expert interviews. They gathered information, and viewed expert advice. This was a way for interns to conduct a reality check - is legal work really in their future?

One student commented:

"I came to an understanding that I do not like legal studies and that it is not fun for me. I enjoyed participating in the legal clinic, but I don't ever see myself being a lawyer or paralegal."

Clarity came to this intern. It is a huge leap to understand yourself. It can be on the job training. [10] The internship is the perfect vehicle for that.

\subsection{Conclusive Discussion}

Though empirical data was gathered regarding the participants in the event and will be reported in another article, only anecdotal data can shape the success of this event. The author's hypotheses that a one-night legal clinic could stand-alone as an internship opportunity for legal studies students is anecdotally reported as successful. All students reported they enjoyed the experience, and administration was happy with the success.

The oral comments from the attorneys after the event was phenomenal-it will be fondly remembered as one of the best ever done. There were hundreds of hours devoted to making the 2014 Free Legal Clinic a success. At the end of the night, organizers felt disappointed because of a glitch in technology. Nevertheless, sixty-five clients were served, twenty-eight attorneys delivered legal services, and sixty students assisted at their side. Interns were there to see the greater good of community service.

\subsection{Addendum: Poster for 2014 Event}

Comments from students: "I really liked the posters too, the large ones used to go to the courthouses were laid out in a great way to draw the attention you were looking for."

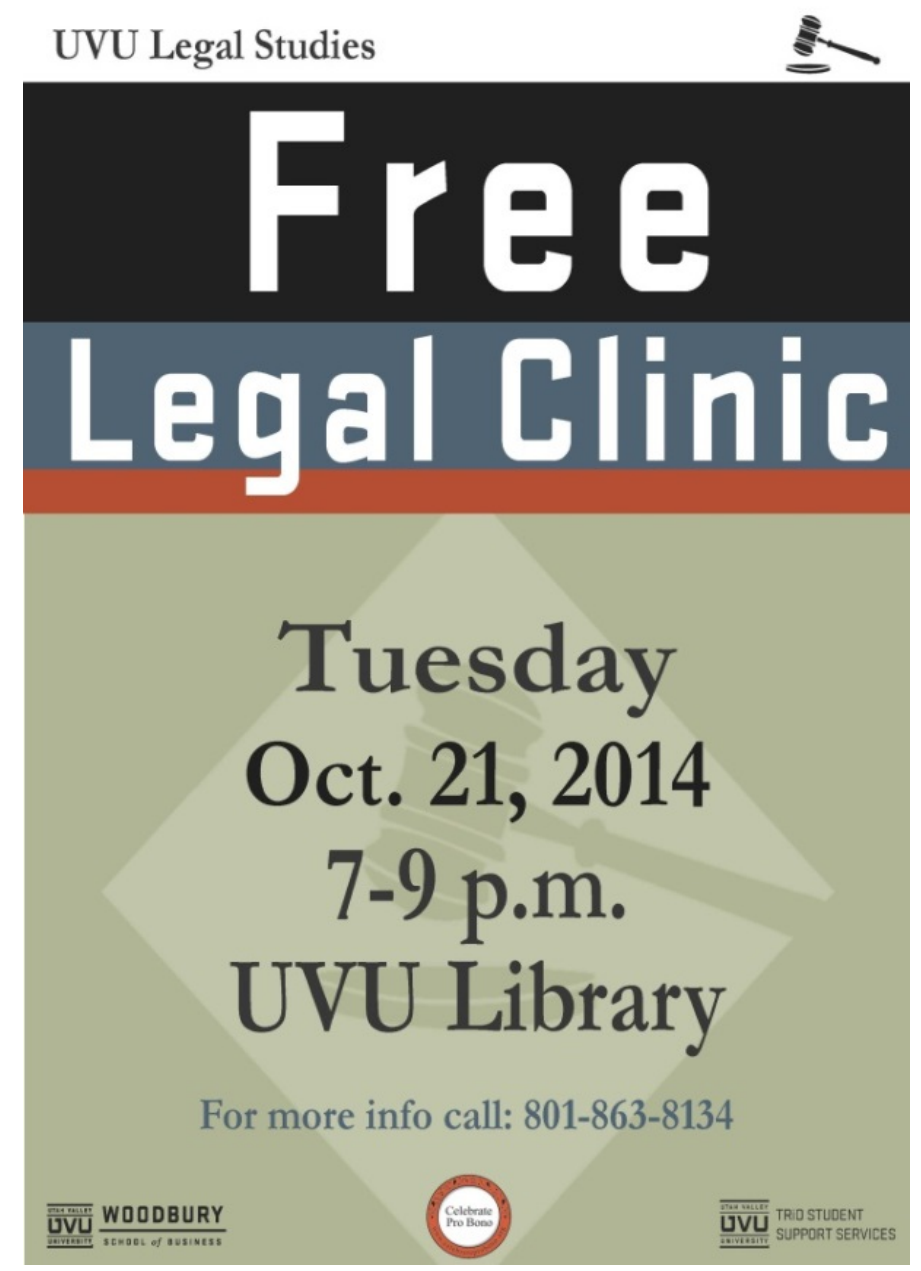

Figure 1. Marketing poster distributed by students for Free Legal Clinic 


\section{Acknowledgements}

Organizers are grateful to all the sponsors, attorneys, clients, and students who participated in the Free Legal Clinics 2009 through 2014.

\section{REFERENCES}

[1] A. Ciofalo, Legitimacy of internships for academic credit remains controversial, Association for Education in Journalism \& Mass Communication, Journalism Educator/Winter pp 25-30, 1989.

[2] G.D. Kuh, High-Impact Educational Practices: What They Are, Who Has Access to Them, and Why They Matter. Association of American Colleges and Universities, USA, 2008.

[3] D.J. Givelber, B.K. Baker, J. McDevitt and R. Miliano, Learning Through Work: An Empirical Study of Legal Internship, Journal of Legal Education, Volume 45 No 1, pp 1-48, (1995).
[4] M. Coco, Internships: A try before you buy arrangement. Business Source Premier, SAM Advanced Management Journal, 65, pp 41-47, 2000.

[5] J. Gault, E. Leach, M. Duey, Effects of business internships on job marketability: the employers' perspective, Emerald Group Publishing Limited, Education + Training, 52, No.1, pp 76-88, 2010.

[6] Online Available: What is an Internship, https://www.uvu.edu/internships/ Accessed 5-23-17

[7] W.M. Tellis, Application of a Case Study Methodology. Nova Southwestern University, The Qualitative Report, Vol 3 No 3, pp 1-19, 1997.

[8] P. Baxter \& S. Jack, Qualitative Case Study Methodology: Study Design and Implementation for Novice Researchers. Nova Southwestern University, The Qualitative Report, Vol 13 No 4, pp 544-559, 2008.

[9] J. Binder, T. Baguley, C. Crook, F. Miller, The Academic value of internships: Benefits across disciplines and student backgrounds. Elsevier, Contemporary Educational Psychology, 41, pp 73-82, 2015.

[10] A. Bernardo, A. Landicho, J.M. Laguador, On-the Job Training performance of Students from AB Paralegal Studies for SY 2013-2014, Studies in Social Sciences and Humanities, Vol 1 No 4, pp 122-129, 2014. 